\title{
Evaluasi Kecepatan Rata-Rata terhadap Kendaraan Arus Bebas (Studi Kasus: Jalan Kolonel Abunjani Kota Jambi)
}

\author{
Eri Dahlan* \\ Universitas Batanghari \\ *Correspondence email: eri.dahlan@unbari.ac.id
}

\begin{abstract}
Abstrak. Tiga faktor penyebab kemacetan lalu lintas yaitu bertambahnya kendaraan bermotor, terbatasnya kemampuan dalam pembangunan jalan raya dan belum optimalnya pengoperasian transportasi massal. Selain kemacetan lalu lintas masalah pada jalan adalah tingkat kecelakaan lalu lintas. kecepatan kendaraan memegang peranan yang penting dalam terjadinya kecelakaan. Jalan Kolonel Abunjani merupakan jalan dalam kota yang memiliki empat lajur dua arah tidak terbagi dan dimana lebar masing lajur 3,75 m. Lebar jalang yang sangat besar dan kondisi jalan yang datar mengakibatkan pengguna jalan cenderung dengan kecepatan yang tinggi. Dari kondisi jalan tersebut berdampak pada tingkat kecelakaan lalu lintas. Sehingga penelitian ini bertujuan untuk evaluasi kecepatan rata-rata kendaraan terehadap kendaraan arus bebas. Hasilnya menunjukan bawa perbandingan antara kecepatan rata-rata untuk sepeda motor $50,46 \mathrm{~km} / \mathrm{jam}$ arah dari Tugu Juang dan $48.01 \mathrm{~km} / \mathrm{jam}$ arah ke Tugu Juang $>$ dengan kecepatan arus bebas 46,04 dengan selisihnya 4,42 km/jam arah dari Tugu Juang dan 1,97 km/jam arah ke Tugu Juang. Kecepatan rata-rata untuk kendaraan ringan 37,37 km/jam arah dari Tugu Juang dan 35,65 km/jam arah ke Tugu Juang > dengan kecepatan arus bebas 37,67 dengan selisihnya 8,67 km/jam arah dari Tugu Juang dan 10,39 km/jam arah ke Tugu Juang. Kecepatan rata-rata untuk kedua kendaraan 43,97 km/jam arah dari Tugu Juang dan 41,82 km/jam arah ke Tugu Juang > dengan kecepatan arus bebas 41,85 dengan selisihnya 2,12 km/jam arah dari Tugu Juang dan 4,21 km/jam arah ke Tugu Juang. Hasil analisa dapat disimpulkan bahwa untuk sepeda motor masih belum aman terhadap kecelakaan.
\end{abstract}

Kata Kunci: Kecepatan Rata-rata, Arus Bebas, Hambatan Samping, Ukuran Kota

\section{PENDAHULUAN}

Secara umum ada tiga faktor penyebab kemacetan lalu lintas yaitu bertambahnya kendaraan bermotor, terbatasnya kemampuan dalam pembangunan jalan raya dan belum optimalnya pengoperasian transportasi massal. Bertambahnya kepemilikan kendaraan bermotor sehingga dapat mengakibatkan penurunan kinerja jalan. Selain kemacetan lalu lintas masalah lain adalah tingkat kecelakaan lalu lintas. Angka kecelakaan lalu lintas kota jambi pada tahun 2019 mengalami peningkatan yaitu dari tahun sebelumnya. Pada tahun 2018 angka kecelakaan sebesar 1.253 kasus menjadi 1.273 kasus di tahun 2019 (Badan Statistik Nasional Jambi, 2020). Dari hasil kajian dilapangan bahwa kecelakaan lalu lintas dipengaruhi oleh faktor manusia (pengemudi dan pejalan kaki), kendaraan, jalan dan lingkungan jalan (Austroats, 2002).

Teori pergerakan lalu lintas, kecepatan kendaraan memegang peranan yang penting dalam terjadinya kecelakaan (WHO,2008). Kecepatan kendaraan mertupakan faktor utama dalam kecelakaan lalu lintas. Tingkat keparahan korban kecelakaan merupakaan fungsi kecepatan. Tingkat kecelakaan di jalan raya diklasifikasikan menjadi fatal accident, serious injury accident, slight injury accident dan property damage accident (Panjaitan,1989). Terjadinya kecelakaan didahului oleh pelanggaraan (Elvin,2004). Beberapa hal yang seringkali terjadi di jalan, seperti mengebut (speeding) menyebabkan tingginya keparahan korban kecelakaan. Risiko kecelakaan meningkat dengan kecepatan kendaraan yang lebih tinggi karena semakin panjang jarak pengereman yang dibutuhkan, kurangnya waktu yang diperlukan untuk memproses dan mengambil keputusan atas informasi yang diperoleh, serta sulitnya mengendalikan kendaraan jika terdapat hambatan di depannya. Secara umum diasumsikan bahwa 1/3 kecelakaan fatal disebabkan oleh kecepatan kendaraan yang tidak sesuai dengan batasan kecepatan (SWOV, 2009).

Kecepatan adalah sebagai suatu laju pergerakan, seperti jarak per satuan waktu, umumnya dalam mil/jam atau kilometer/jam. Karena begitu beragamnya kecepatan individual dalam aliran lalu lintas, maka kita biasanya menggunakan kecepatan rata-rata. Waktu tempuh $\mathrm{t}_{1}, \mathrm{t}_{2}, \mathrm{t}_{3}, \ldots ., \mathrm{t}_{\mathrm{n}}$ diamati untuk $\mathrm{n}$ kendaraan yang melalui suatu ruas jalan sepanjang 1 (Khisty, 2003).

Jalan Kolonel Abunjani merupakan jalan dalam kota yang memiliki tipe jalan empat lajur dua arah tidak terbagi dan dimana lebar masing lajur 3,75 m. Lebar jalang yang sangat besar dan kondisi jalan yang datar mengakibatkan pengguna jalan cenderung dengan kecepatan yang tinggi. Pada jam sibuk kondisi jalan memiliki kepadatan lalu lintas yang tinggi. Dari kondisi jalan tersebut berdampak pada tingkat kecelakaan lalu lintas. Sehingga penelitian ini bertujuan untuk evaluasi kecepatan rata-rata kendaraan terhadap kendaraan arus bebas.

\section{METODE}

Analisis yang digunakan adalah dengan membandingkan kecepatan rata-rata kendaraan dengan kendaraan arus bebas. Kecepatan rata-rata $(\mathrm{km} / \mathrm{jam})$ arus lalu-lintas dihitung dari panjang jalan dibagi waktu tempuh rata-rata 
kendaraan yang melalui segmen jalan (Bina Marga, 1997). Perhitungan kecepatan sesungguhnya lokasi penelitian dapat dilihat pada persamaan 1. Perhitungan kecepatan arus bebas dengan menggunakan Manual Kapasitas Jalan Indonesia (MKJI). Perhitungan arus bebas dapat dilihat pada persamaan 2.

$\mathrm{V}=\mathrm{L} / \mathrm{t}$

dimana:

$\mathrm{V} \quad=$ Kecepatan kendaraan $(\mathrm{m} / \mathrm{det})$

$\mathrm{L} \quad=$ Jarak tempuh kendaraan $(\mathrm{km})$

$\mathrm{t} \quad=$ Waktu tempuh kendaraan (det)

Arus bebas adalah Kecepatan rata-rata teoritis $(\mathrm{km} / \mathrm{jam})$ lalu-lintas pada kerapatan $=0$, yaitu tidak ada kendaraan yang lewat. Kecepatan $(\mathrm{km} / \mathrm{jam})$ kendaraan yang tidak dipengaruhi oleh kendaraan lain (yaitu kecepatan dimana pengendara merasakan perjalanan yang nyaman, dalam kondisi geometrik, lingkungan dan pengaturan lalulintas yang ada, pada segmen jalan dimana tidak ada kendaraan yang lain) (Bina Marga, 1997). Perhitungan arus bebas sebagai berikut:

$\mathrm{FV}=\left(\mathrm{FV}_{0}+\mathrm{FV}_{\mathrm{W}}\right) \times \mathrm{FFV}_{\mathrm{SF}} \mathrm{xFFV}$ CS

dimana:

$\mathrm{FV} \quad=$ Kecepatan arus bebas kendaraan ringan sesungguhnya $(\mathrm{km} / \mathrm{jam})$

$\mathrm{FV}_{0} \quad=$ Kecepatan arus bebas dasar kendaraan ringan $(\mathrm{km} / \mathrm{jam})$

$\mathrm{FV}_{\mathrm{W}}=$ Kecepatan arus bebas penyesuaian lebar lajur efektif $(\mathrm{km} / \mathrm{jam})$

$\mathrm{FFV}_{\mathrm{SF}}=$ Faktor penyesuaian hambatan samping

$\mathrm{FFV}_{\mathrm{CS}}=$ Faktor penyesuaian ukuran kota

\section{HASIL DAN PEMBAHASAN}

Penelitian di Jalan Kolonel Abunjani yang memiliki jenis jalan 4 lajur 2 arah tidak terbagi yang berdasarkan hasil pengukuran geometrik dapat dilihat pada tabel 1 .

Tabel 1. Geometrik ruas Jalan Kolonel Abunjani

\begin{tabular}{ccccc}
\hline Nama Jalan & $\begin{array}{c}\text { Panjang Jalan } \\
\text { yang Ditinjau }\end{array}$ & \multicolumn{3}{c}{ Lebar Bagian Jalan } \\
& Lajur Lalin & Trotoar & Drainase \\
\hline Jl. H. Agus Salim & $550 \mathrm{~m}$ & $4 \times 3,75$ & $1 \mathrm{~m}$ & $2 \times 1,00$ \\
\hline
\end{tabular}

Sumber: Data Olahan, 2021

Jalan ini merupakan jalan yang menghubungkan pusat kegiatan wilayah dengan pusat kegiatan lingkungan, antar pusat kegiatan lokal, atau pusat kegiatan lokal dengan pusat kegiatan lingkungan, serta antarpusat kegiatan lingkungan. Ruas Jalan Kolonel Abunjani memiliki jalan empat lajur dua arah tidak terbagi (4/2 UD).

Kecepatan lalu lintas didapat dari survei yang dilakukan pada 08 September 2020. Kecepatan yang didapat tiap 15 menit kemudian dikonfersi menjadi $\mathrm{km} / \mathrm{jam}$. Data kecepatan yang didapatkan untuk dianalisis menganalisis kecepatan rara-rata kendaraan dengan persamaan 1. Pengambilan data jenis kendaraan yang dihitung adalah kendaraan ringan dan sepeda motor. Data kecepatan lalu lintas dapat dilihat pada Gambar 1 dan Gambar 2.

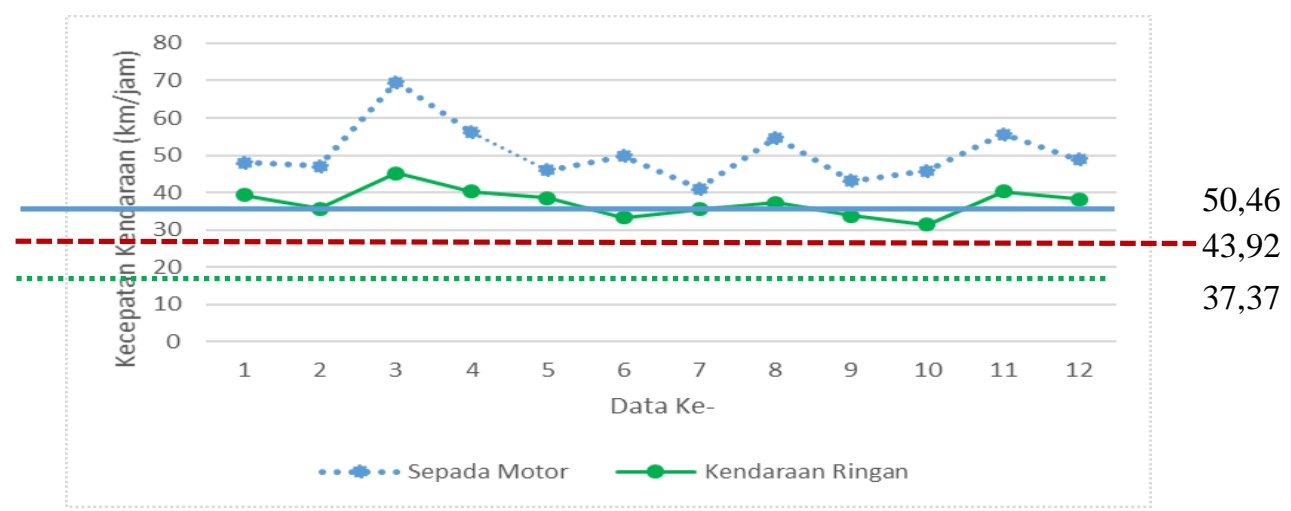

Gambar 1. Kecepatan dari Tugu Juang

Sumber: Data Olahan, 2021 
Dari Gambar 1. kecepatan lalu lintas tertinggi untuk sepeda motor adalah 69,59 km/jam dan kendaraan ringan $45,23 \mathrm{~km} / \mathrm{jam}$. Kecepatan terendah untuk sepeda motor $41.06 \mathrm{~km} / \mathrm{jam}$ dan kendaraan ringa 31,33 km/jam. Kecepatan rata-rata untuk sepedamotor $50,56 \mathrm{~km} / \mathrm{jam}$ kendaraan ringa $37,37 \mathrm{~km} / \mathrm{jam}$. Untuk cepetan rata-rata kendaraan ke dua tipe kendaraan tersebut adalah $43,92 \mathrm{~km} / \mathrm{jam}$.

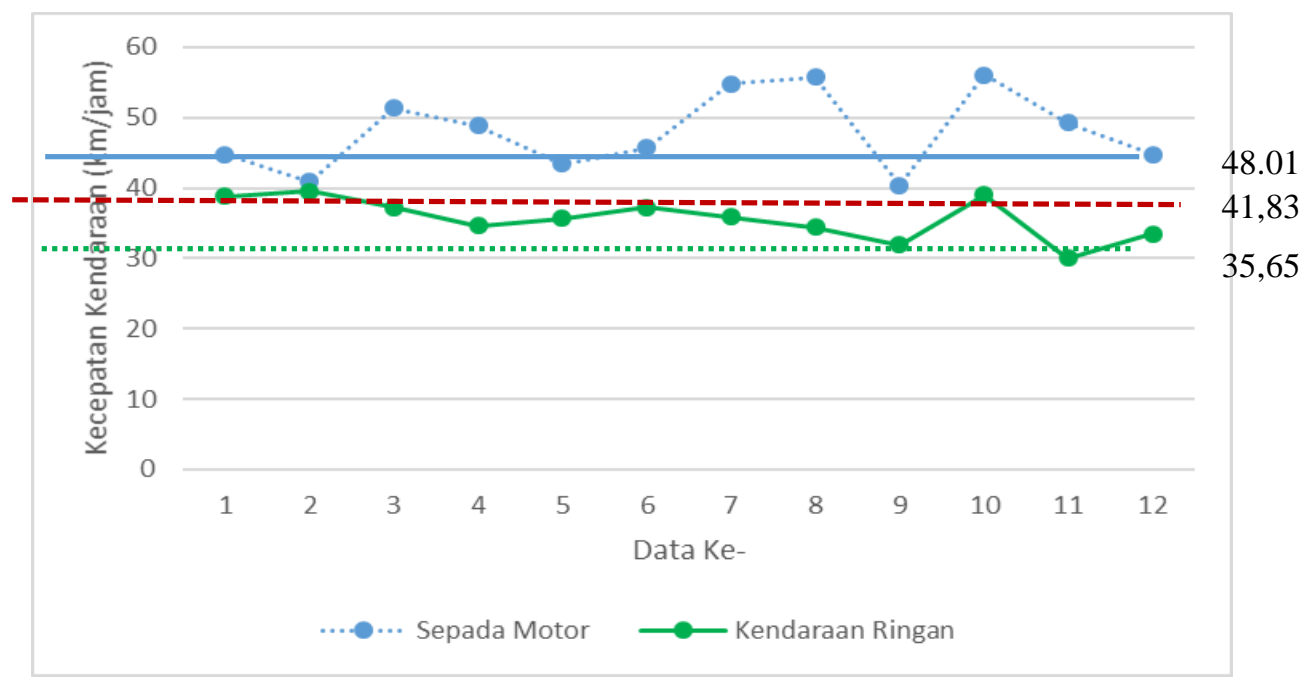

Gambar 2. Kecepatan lalu lintas ke Tugu Juang

Sumber: Data Olahan, 2021

Dari Gambar 2. kecepatan lalu lintas tertinggi untuk sepeda motor adalah $56.08 \mathrm{~km} / \mathrm{jam}$ dan kendaraan ringan $39.54 \mathrm{~km} / \mathrm{jam}$. Kecepatan terendah untuk sepeda motor 40,40 km/jam dan kendaraan ringa 30,03 km/jam. Kecepatan rata-rata untuk sepedamotor $48.01 \mathrm{~km} / \mathrm{jam}$ kendaraan ringa 35,65 km/jam. Untuk cepetan rata-rata kendaraan ke dua tipe kendaraan tersebut adalah $41,83 \mathrm{~km} / \mathrm{jam}$.

Analisis kecepatan arus bebas kendaraan dengan Manual Kapasitas Jalan Idonesia (MKJI 1997). Perhitungan kecepatan arus bebas dengan menggunakan persamaan 2 dan untuk data geometri jalan dapat dilihat pada Tabel 1. Hasil perhitungan pada Tabel 2.

Tabel 2. Perhitungan Kecepatan Arus Bebas (FV)

\begin{tabular}{lccccc}
\hline JENIS KENDARAAN & FV $_{\mathbf{0}}$ & $\mathbf{F V}_{\mathbf{W}}$ & $\mathbf{F F V}_{\mathbf{S F}}$ & $\mathbf{F F V}_{\mathbf{C S}}$ & FV \\
\hline Kendaraan Ringan & 53 & 2 & 0,93 & 0,90 & 46,04 \\
Sepeda Motor & 43 & 2 & 0,93 & 0,90 & 37,67 \\
Kecepatan rata-rata & 48 & 2 & 0,93 & 0,90 & 41,85 \\
\hline
\end{tabular}

Sumber: Data Olahan, 2021

Berdasarkan hitungan kecepatan rata-rata memiliki nilai lebih besar dari pada kecepatan arus bebas hasil perhitungan dengan Manual Kapasitas Jalan Idonesia (MKJI 1997) adalah sepeda motor sedangkan untuk kecepatan rata-rata kendaraan ringan dan kecepatan rata-rata kedua kendaraan lebih kecil dibandingkan dengan kecepatan arus bebas hasil perhitungan dengan Manual Kapasitas Jalan Idonesia (MKJI 1997). Kecepatan arus bebas Parbandingan kecepatan rata-rata kendaraan pada Tabel 3.

Tabel 3. Kecepatan Rata-rata dengan Kecepatan Arus Bebas

\begin{tabular}{cccc}
\hline \multirow{2}{*}{ Jenis Kendaraan } & \multicolumn{2}{c}{ Kecepatan Rata-rata } & \multirow{2}{*}{ Kecepatan Arus Bebas } \\
\hline Kendaraan Ringan & 37,37 & 35,65 & 37,67 \\
Sepeda Motor & 50,56 & 48,01 & 46,04 \\
Kecepatan rata-rata & 43,92 & 41,83 & 41,85 \\
\hline
\end{tabular}

Sumber: Data Olahan, 2021

\section{SIMPULAN}

Hasil analisis menunjukan bahwa kecepatan rata-rata sepeda motor melebihi kecepatan arus bebas dengan selisih kecepatan $4.42 \mathrm{~km} / \mathrm{jam}$ arah dari Tugu Pejuang dan 1,97 km/jam arah ke Tugu Pejuang sehingga berbanding terbak dengan kondisi keamanan pada jalan. Sedangka kendaraan ringan dan kecepatan rata-rata kedua kendaraan lebih kecil di banding arus bebas sehingga kecepatan untuk kendaraan ringan dan kedua kendaraan akan aman pada 
jalan. Selisih kecepatan arus bebas kendaraan ringan dengan kecepatan rata-rata adalah 8,67 km/jam arah dari Tugu Pejuang dan 10,39 km/jam arah ke Tugu Pejuang. Selisih kecepatan arus bebas kedua kendaraan dengan kecepatan rata-rata adalah 2,12 km/jam arah dari Tugu Pejuang dan 4,21 km/jam arah ke Tugu Pejuang.

\section{DAFTAR PUSTAKA}

Austroats, 2002, Road Safety Audit $2^{\text {nd }}$ Edition, Standart Association of Australia

Badan Statistik Nasional Jambi, 2020, Kota Jambi Dalam Angka 2020, Jambi.

Bina Marga, 1997, Manual Kapasitas Jalan Indonesia (MKJI), Jakarta.

Elvik, R., Christensen P. and Amundsen A. 2004. Speed and road accidents; An evaluation of the Power Model. Institute of Transport Economics. Oslo.

Institute for Road Safety Research, 2009, The Relation Between Speed and Crashes, SWOV, Leidschendam.

Khisty, C., Jotin, K. dan Lall, B. Kent, 2003, Dasar-dasar Rekayasa Transportasi Jilid 1, Erlangga, Jakarta.

Penjaitan Taruli, 1989, Analissa Kecelakaan pada LokasiRawan Kecelakaan di Kota Jakarta, Karya Ilmiah, FTUI, Jakarta.

World Health Organization, FIA Foundation, Global Road Safety Partnership, and The World Bank, 2008, Speed Management: a Road Safety Manual for Decision-Makers and Practitioner, Geneva 